blessing of the church. It is of interest here to note that the church of San Francisco in Tlaxcala, Mexico, is the first church erected on the American continent, and still contains the vestments, pulpit, font, and cedar ceiling brought from Spain in I 521 .

\title{
The Trotter Manuscripts
}

Among the collections of business records brought together by the Business Historical Society and Baker Library there is one which is outstanding for its size, its completeness, and for the fact that it represents a longer period of time than any other single collection. This is the Trotter collection, the records of a family of Quaker merchants of Philadelphia. There are 1075 volumes of records which include some thirty different types of books. The whole group covers the years $1798-1916$. The material has been mentioned before in the Bulletin, but no adequate description of the entire collection has appeared.

The Trotter manuscripts are important in that they comprise the records of a firm characteristic in many ways of the great mass of American business. The company was not spectacular either in its origin or its development, yet it was founded on sufficiently sound principles to insure its continuance for $\mathrm{I}_{4} 2$ years and it is still a going concern. The Trotter Company may be thought of as a company of metal importers, though the importance of that phase of the business varied greatly from time to time. The firm is distinctly a middleman's firm. They bought at wholesale and sold at wholesale.

We are told by the family that the company was first organized under the name of William Trotter in 1789 . However, there are no records which antedate 1798 . In the early years of the business William Trotter was closely associated with Joseph Sanson, for whom, we are told, William Trotter had worked as a boy. Joseph Sanson seems to have assumed the responsibility of establishing the credit of William Trotter abroad and of launching him out on new enterprises. By I808 we find that William's younger brother, Nathan Trotter, was working for him and we know that in 1809 the name of the firm became William Trotter and Company. In I8I 3 the name was changed again to William and Nathan Trotter. In I8I 5 William Trotter died, while still a young man, and Nathan 


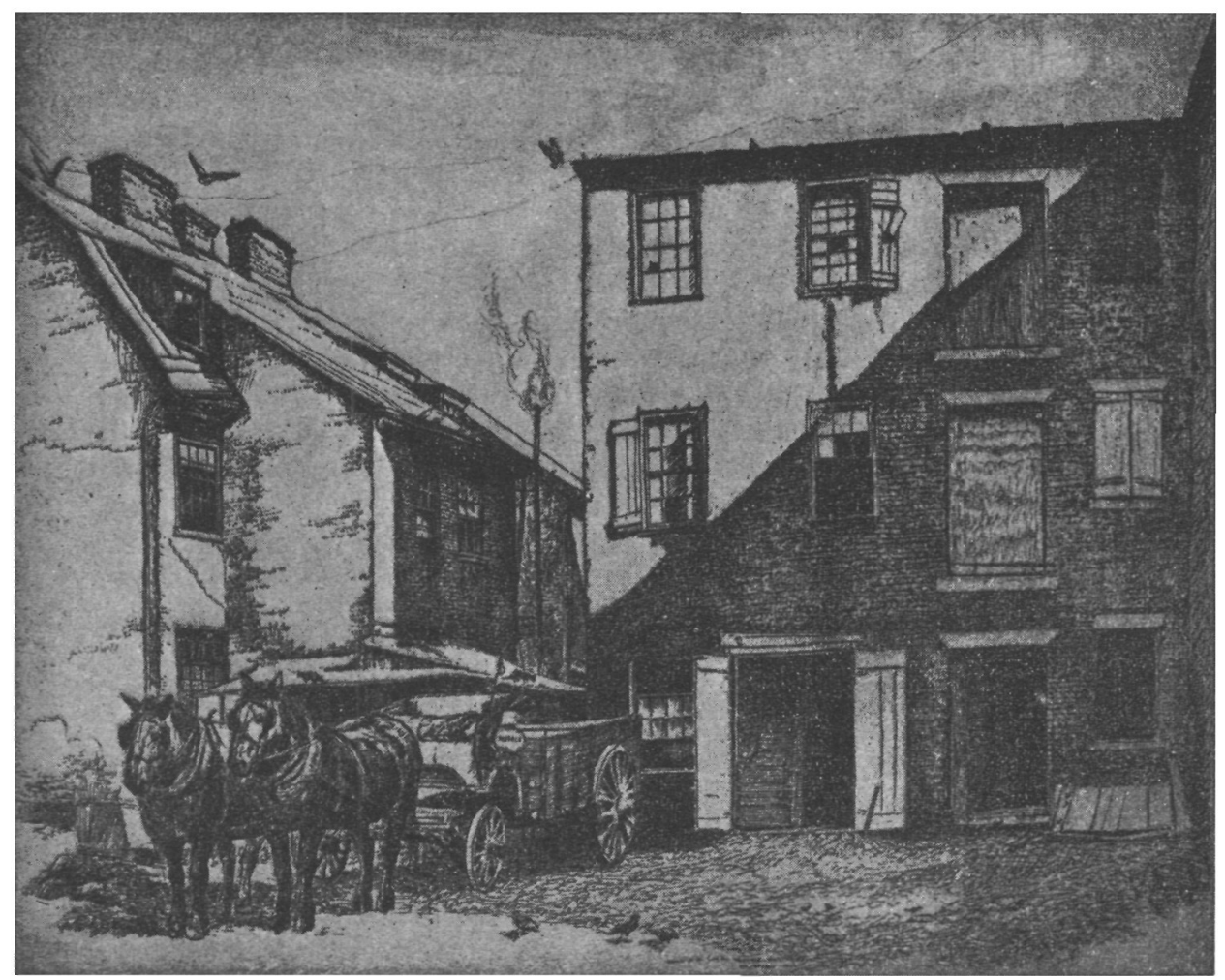

\section{The Nathan Trotter and Company Warehouse Etching by Howard Cook}


took over the responsibility of the company, the name being changed to Nathan Trotter and Company, under which it still exists.

Nathan Trotter and Company was a family partnership in which Nathan's brother Joseph was associated with him until 1830. Between 1830 and 1850 Nathan's two oldest sons, Edward H. Trotter and George Trotter, became partners and in $185^{\circ}$ owned equal shares with their father. In the year 1850 there was a reorganization of the company. Nathan Trotter retired from business and the two younger sons joined the partnership. The interests of the partners were as follows: Edward $\mathrm{H}$. Trotter 30

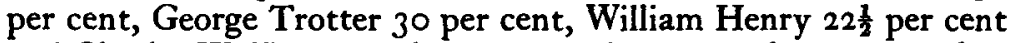
and Charles W. Trotter $17^{\frac{1}{2}}$ per cent. Since 1877 the company has been in the hands of sons of William Henry Trotter - Nathan Trotter, Edward H. Trotter and William Henry Trotter. At the time the papers were presented to the Library, William Henry Trotter was president of the firm, and it was through him that the records were given.

Since Nathan Trotter and Company is entirely a marketing organization, which both bought and sold at wholesale, its history had two primary phases - the source of goods purchased and the marketing area.

Taking up the first, we find that in the early years the firm dealt in a wide variety of commodities - cloth, leather, various kinds of metal and manufactured metal ware, mostly imported from English firms. Beginning with 1806 the continuous interruptions in trade caused by the Napoleonic Wars, and culminating in the War of 1812 , led Trotter to first seek in this country goods formerly imported from England and later led him to establish trade with China and India. From China came tea, china, nankeens, silks, and shawls; from Calcutta came saltpeter, goat skins, indigo, and shellac.

After the War of 1812 trade was resumed with England and gradually the trade with India and China came to a close.

Nathan Trotter, the most doninant figure in the history of the company, early grasped the idea of specialization. The less important commodities began to disappear from the records. By the 'thirties the Trotter company was dealing primarily in iron, steel, copper, brass, and tin, imported from England and Wales. From $183^{\circ}$ on, the history of the company is largely the struggle between the imported metals and the domestic metals which were 
continually increasing in quantity and quality of production. Imported metals continued to be predominantly from England and Wales, though from the 'fifties to the 'seventies large importations of Malacca tin were brought from Singapore, Banca tin from Rotterdam and iron from Russia. With the aid of the tariff, however, home producers were steadily replacing foreign producers in supplying the Trotter Company. By the 'nineties their only importations were of slab tin and these were decreasing in importance. In 1890 there were eighty such invoices, in 1907 there were two, and in 1912 thirteen.

In regard to the marketing area we see certain interesting changes. In the very early years sales of goods were made primarily to people near at hand and in small quantities, for many of their customers were blacksmiths. Soon, however, the marketing area was enlarged. By 1810 they were selling goods in Pittsburgh and other more distant points, but not without increased difficulty in collecting debts. In time Nathan Trotter and Company had many customers in the Middle West and it was once proposed to the company that they establish a branch office in San Francisco.

In 1877 there was an attempt to have goods, shipped from abroad and charged to them, consigned directly to their customers in Chicago, Cincinnati, Louisville, St. Louis and Pittsburgh. Though this method did not succeed at this time, we are told that at present the Trotter Company does not maintain a warehouse, but buys goods to be shipped directly to their customers.

The early records of the firm are clearly stamped as those of a Quaker merchant. Not only the quaint phrases of salutation, but the entire attitude make the letters stand apart from the usual business correspondence even of that day. The following transcriptions of two letters from one of the early letter books clearly illustrate this point:

Esteemed Friends

Philada July $3^{\text {st }}$ I 8 I 2

Prischell \& Schreiber

My last was of date 13 March - since which I have rec ${ }^{d}$ your esteemed favor of 15 May inclosing protest for non-acceptance for bill on Rob Torsey - the Indorsers here think it is probable that funds may yet go into the hands of the house in London.

As our two countries are now unhappily involved in a state of war, Trade and intercourse must consequently stop. I must beg your attention to my interest - a line from you would be satisfactory - how long this deplorable Calamity will last it is impossible at present to foresee, but 
having now come in collision it is hoped all sides will see their interest in the blessing of Peace, and give us a speedy and honorable one.

With much regard, I remain your Friend

W. T.

Esteemed Friends

Philad 8 May I8I9

Bainbridge \& Brown

We have duly noticed the contents of all your letters and by the tenor $\&$ words of some of them we began to conclude that owing to the difficulty of the times and the distressed state of trade generally confidence was so exceedingly impaired that you had declined any other than cash business -We must confess we were disappointed in not receiving any copper at all and could only impute it to some fear in your minds as to the general result of these times of uncommon difficulty - and at first a little hurt as we were conscious our remittances had not been the most tardy and we had your acknowledgements that they had been satisfactory - upon a little reflection however we were glad that you had not sent any as we would much rather our friends would not credit us one cent than that they should create a particle of uneasiness in their minds by doing it and we have no doubt you acted as in your judgement you thought the existing state of things required and we think that you were perfectly right in doing so and as respects ourselves feel quite satisfied - things continue here in a very unsettled state and many are feeling the unpleasant effects of a business that has been entirely too extended for their actual means \& not calculated to stand such times as these-We still think it will tend to bring matters to a proper level of security and that future opperations, will be more guarded \& more in proportion to the real capital employed - As to ourselves we dont know that we shall suffer much loss by the times, tho' as is generally the case we find many of our customers very tardy in payment, tho' but in few instances do we think we shall sustain any loss, and upon the score of indorsements or other guarantee we are not liable for one cent in any way or for any person-We write to you not as chance or temporary correspondents but as particular friends, who have extended credit to us more than we ever asked of any other house, and therefore we write openly and candidly and as our feelings dictate. . . . We shall probably write again in a few days. Meantime we are your assured friends,

\section{/Signed/Nathan Trotter \& Co}

Such a collection as here described cannot but be of great value to business and economic research. At present one student is writing a doctor's dissertation from the material. The records are also to be used in the Philadelphia Price Study which is to form a part of the International Price Study. 